\title{
Interferon gamma (IFNg) production is associated to disease parameters in TLR9-induced secondary hemophagocytic lymphohistiocytosis (sHLH) in mice
}

\author{
Cristina De Min ${ }^{1 *}$, Vanessa Buatois ${ }^{2}$, Laurence Chatel ${ }^{2}$, Laura Cons², Marie Kosco-Vilbois², Walter Ferlin² \\ From 21st European Pediatric Rheumatology (PReS) Congress \\ Belgrade, Serbia. 17-21 September 2014
}

\section{Introduction}

IFNg is the pivotal mediator in the murine model of primary HLH. Mice given repeated injection with the TLR9 agonist, CpG-containing oligodeoxynucleotides, develop pathology resembling the human disease, sHLH. Coadministration of an anti-IL-10 Receptor (R) monoclonal antibody $(\mathrm{mAb})$ with $\mathrm{CpG}$ induces more severe disease characterized also by hemophagocytosis (fulminant sHLH).

\section{Objectives}

We evaluated whether the neutralization of IFNg in murin sHLH and fulminant sHLH affected the disease features and we investigated whether treatment with an anti-IFNg $\mathrm{mAb}$ affected the clinical and laboratory features in murine models of sHLH and fulminant sHLH; we also exploited the in vivo principle that, in the presence of an anti-IFNg antibody, circulating IFNg bound to the antibody is incorporated in a complex leading to accumulation of the cytokine in serum, therefore allowing the quantification of IFNg production.

\section{Methods}

C57BL/6 mice received i.p. injections of CpG on days 0 , 2, 4, 7 \& 9. Neutralizing IL-10R, mAb 1B1.3A at $200 \mu \mathrm{g} /$ mouse (days $0,2,4,6$ ), and anti-mouse IFNg, mAb XMG1.2 at $100 \mathrm{mg} / \mathrm{kg}($ days $1,3,6)$ were administered i.v..

\section{Results}

In murine sHLH, the neutralization of IFNg caused a reduction in body weight loss and splenomegaly, normalized white blood cell counts and hyperferritinemia, and corrected anemia. Blockade of IFNg in mice with fulminant sHLH improved key disease features by decreasing the body weight loss by $20 \%$, reduced splenomegaly by $23 \%$, improved anemic parameters by $13 \%$, reversed cytopenia by $30 \%$ and normalized sHLHassociated cytokine storm as evidenced by a $60 \%$ decrease in circulating levels of TNF $\alpha$. Circulating levels of IFNg reached steady state at $250 \mathrm{ng} / \mathrm{ml}$ in both models (sHLH and fulminant sHLH). Expression of IFNginduced inflammatory genes demonstrated that spleen and liver are major sites of IFNg production.

\section{Conclusion}

Neutralization of IFNg appears to effectively improve the clinical and laboratory features in the CpG-induced models of sHLH, including fulminant sHLH. These data offer a rationale for the neutralization of IFNg as a potential targeted therapeutic approach in patients with severe form of sHLH.

\section{Disclosure of interest}

None declared. 


\section{Authors' details}

${ }^{1}$ Clinical Development, Novlmmune SA, Plan-Les-Ouates Geneve, Switzerland.

${ }^{2}$ Pre-clinical Development, NovImmune SA, Plan-Les-Ouates Geneve,

Switzerland.

Published: 17 September 2014

doi:10.1186/1546-0096-12-S1-02

Cite this article as: De Min et al:: Interferon gamma (IFNg) production is associated to disease parameters in TLR9-induced secondary

hemophagocytic lymphohistiocytosis (sHLH) in mice. Pediatric

Rheumatology 2014 12(Suppl 1):O2.

Submit your next manuscript to BioMed Central and take full advantage of:

- Convenient online submission

- Thorough peer review

- No space constraints or color figure charges

- Immediate publication on acceptance

- Inclusion in PubMed, CAS, Scopus and Google Scholar

- Research which is freely available for redistribution

Submit your manuscript at 